\title{
Design of Information Systems in Support of Nutrition Services Based on Halal Assurance Certification in Hospitals
}

\author{
Febitya Valent Difiana ${ }^{1}$, Apoina Kartini ${ }^{2}$, Ratih Sari Wardani ${ }^{3}$
}

\author{
${ }^{1}$ Magister of Public Health, Diponegoro University, Semarang, Indonesia \\ ${ }^{2}$ Lecturers for Masters in Public Health, Diponegoro University, Semarang, Indonesia \\ ${ }^{3}$ Public Health Lecturer, Muhammadiyah University, Semarang, Indonesia \\ Received: 13 Nov 2020; Received in revised form: 05 Dec 2020; Accepted: 11 Dec 2020; Available online: 17 Dec 2020 \\ (C)2020 The Author(s). Published by Infogain Publication. This is an open access article under the CC BY license \\ (https://creativecommons.org/licenses/by/4.0/).
}

\begin{abstract}
Information systems are needed by hospitals. Because in the hospital it needs of a system that facilitates the improvement of performance and services to patients This study aims to develop an information system to support nutritional services based on halal assurance certification in hospitals. This research is an important initial process of analysis because it becomes a determinant in the next process. The method used in this research is Action Research to make it easier to analyze problems qualitatively and to use the System Development Life Cycle with a prototype model as a determination in analyzing system requirements. The results show that with Windows 10 as an operating system with an Intel $R$ Celeron processor and using the MySQL programming language, it can produce a prototype with the interface design that the hospital needs. the resulting system is in line with expectations, is useful, and can assist hospitals in halal assurance certification.
\end{abstract}

Keyword-Information System, Nutrition Services, Prototype, HAS, Hospital.

\section{INTRODUCTION}

Technology is useful in helping every human being to solve problems by using it according to our needs. (Anthony et al., 2017). An understanding of information systems and technology is needed for any agency because the role of information is so important to make it easier to access information for related parties, especially in hospitals (Ifan S., Kodar S., 2016) Because the hospital is a health service that will not separate from the development of science and technology in each of its activities (Gunawan K., 2002)

To facilitate hospitals to support nutritional services, an information system is needed to make it more efficient and make it easier to improve service performance to patients (Mutalazimah et al., 2009). In nutritional services, it is necessary to have halal certification in all aspects related to food, starting from how to get food, processing, distributing and serving food (Nurul Huda, 2012) and based on law No. 33 of 2014 article 4: all products traded and circulating in Indonesia are required to be halal certified. The halal certificate has a validity period of 5 years. Therefore it is necessary to carry out renewal in fulfilling the requirements for halal certification. Making the information system requires a system analysis. Because analyzing system requirements become something important in the development and manufacture of information systems to become the initial foundation in the next steps. (Hadi P., 2016)

\section{METHOD}

The research was conducted at the PKU Muhammadiyah Temanggung Islamic Hospital. The object of this research is the nutrition service information system 
for halal assurance certification. The method used is a qualitative method using action research which is analyzed using a weighted average. The following is an explanation of the action research process (Hasan, 2009):

\section{1) Planning}

Gather data to be able to be diagnosed in depth.

\section{2) Implementation}

Take the implementation action

\section{3) Observation}

The results of the intervention in the form of data were collected and then analyzed.

\section{4) Reflection}

Solved a problem.

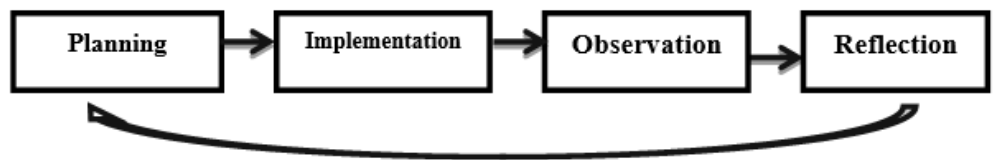

Fig.1: Action Research Method

The qualitative variables used are data collection at the hospital and supporting information obtained from in-depth interviews, observations, and questionnaires. The subjects in this study were the Head of Nutrition 1 person, 2 nutritionists, and 1 support manager as triangulation informants. For validity and reliability, it uses triangulation because it can check data from various sources in various ways and at various times. (Sugiyono, 2015) For system quality, it is assessed using the SUS (System Usability Scale) because measuring using SUS can be relied on in various measures to achieve goals quickly and reliably. (Konstantina et al., 2014)SUS itself is a test that includes end-users in the process (Usman, 2019)

As well as choosing a Likert scale to measure the quality of the information obtained. The Likert scale function is designed to measure attitudes in legal acceptance in specific combinations of the problem (Ankur Josi et al., 2015) For system design using a prototype model. The prototype was chosen because the prototype can provide convenience in the development and development of information systems, especially in making web features. (Rompis,2013) (Dwi Purnomo, 2017).

The general research design is as follows:

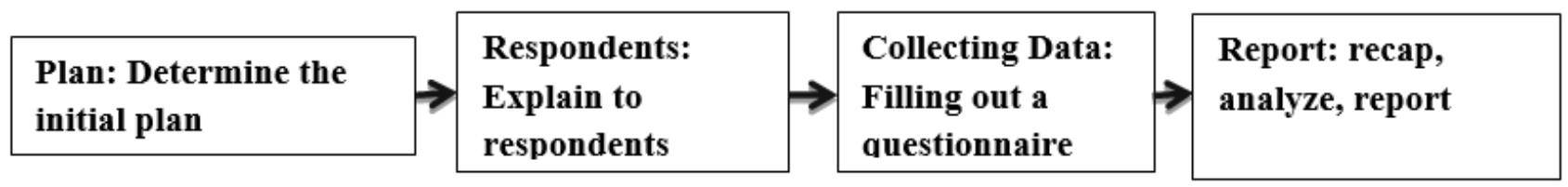

Fig.2: The flow of the System Usability Scale

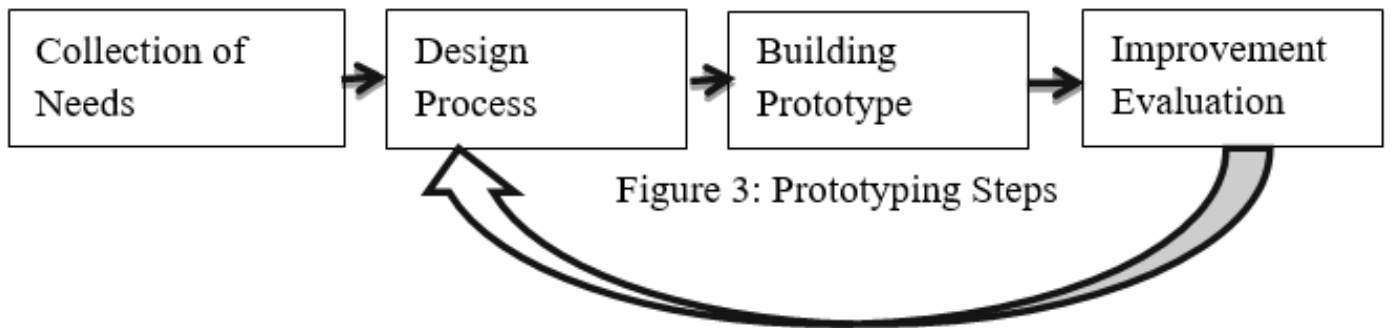

Fig.3: Prototyping Steps 


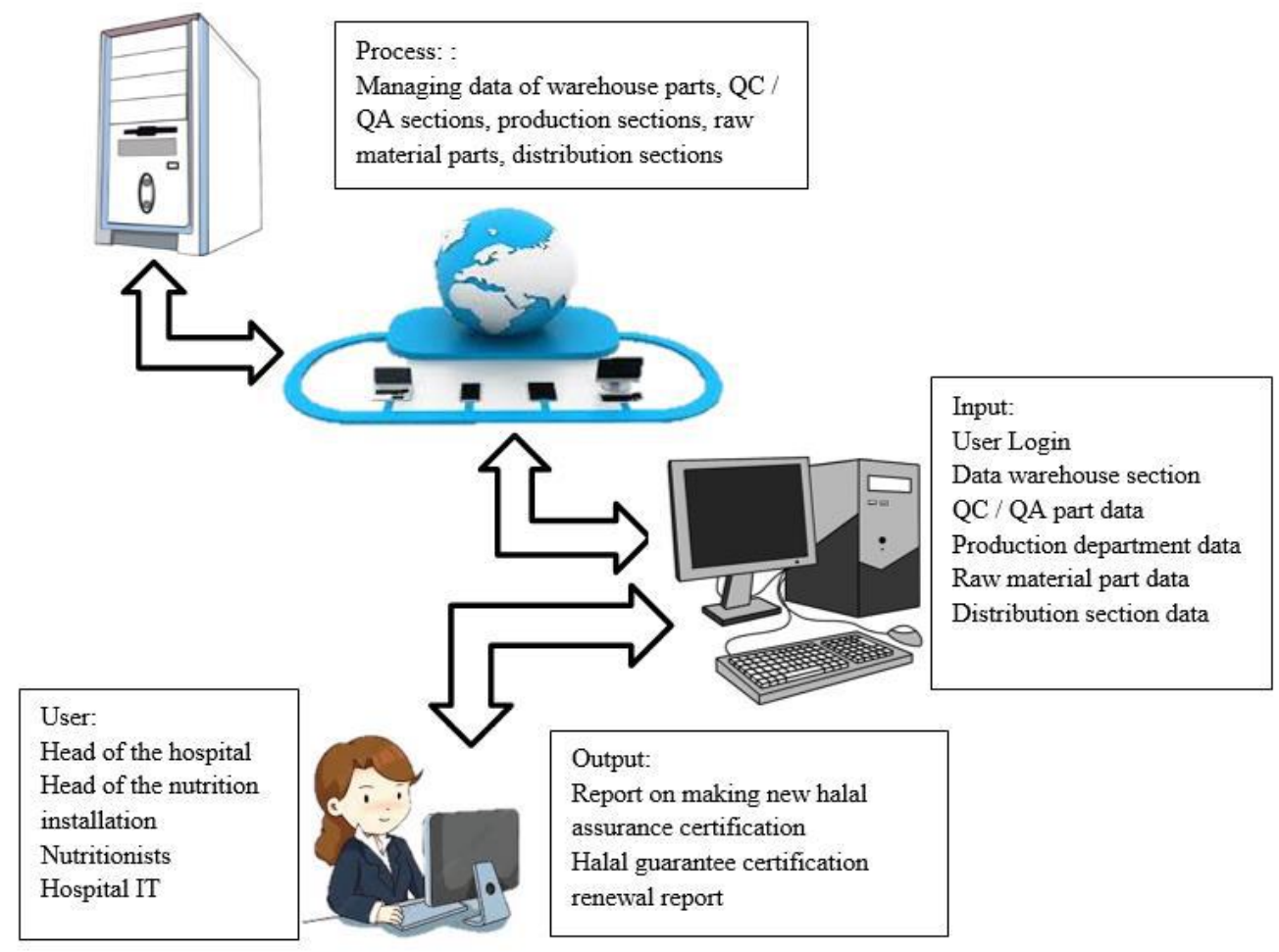

Fig.4: Image General System Design

\section{5) DFD (Data Flow Diagram)}

Data Flow Diagrams (DFD) are used as a depiction of information flowing from input to output. DFD proposed are as follows :

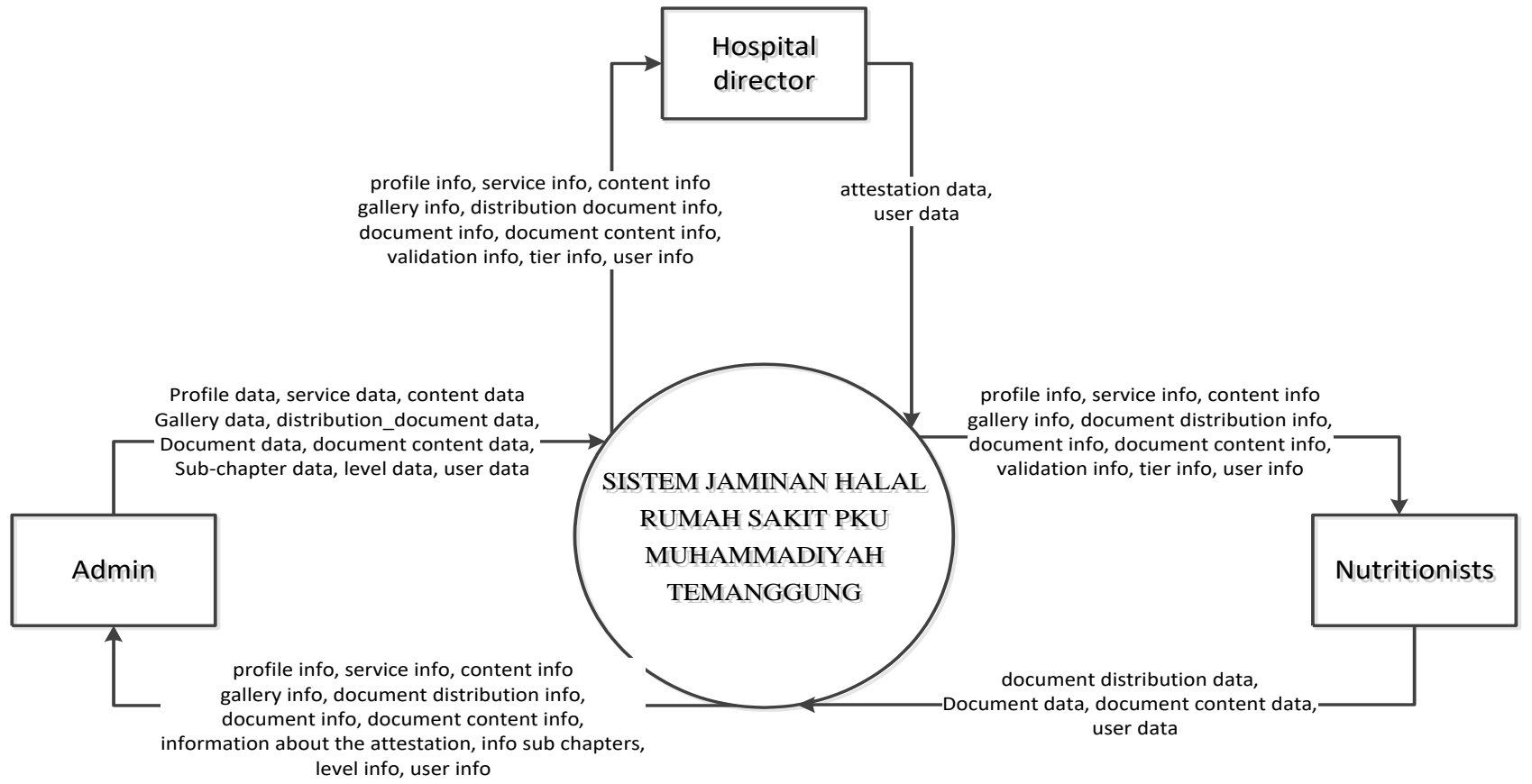

Fig.5: Context Diagram 


\section{6) Level 1 diagram}

The following is a level 1 diagram, Information Systems in Support of Nutritional Services Based on Halal Assurance Certification in Hospitals:

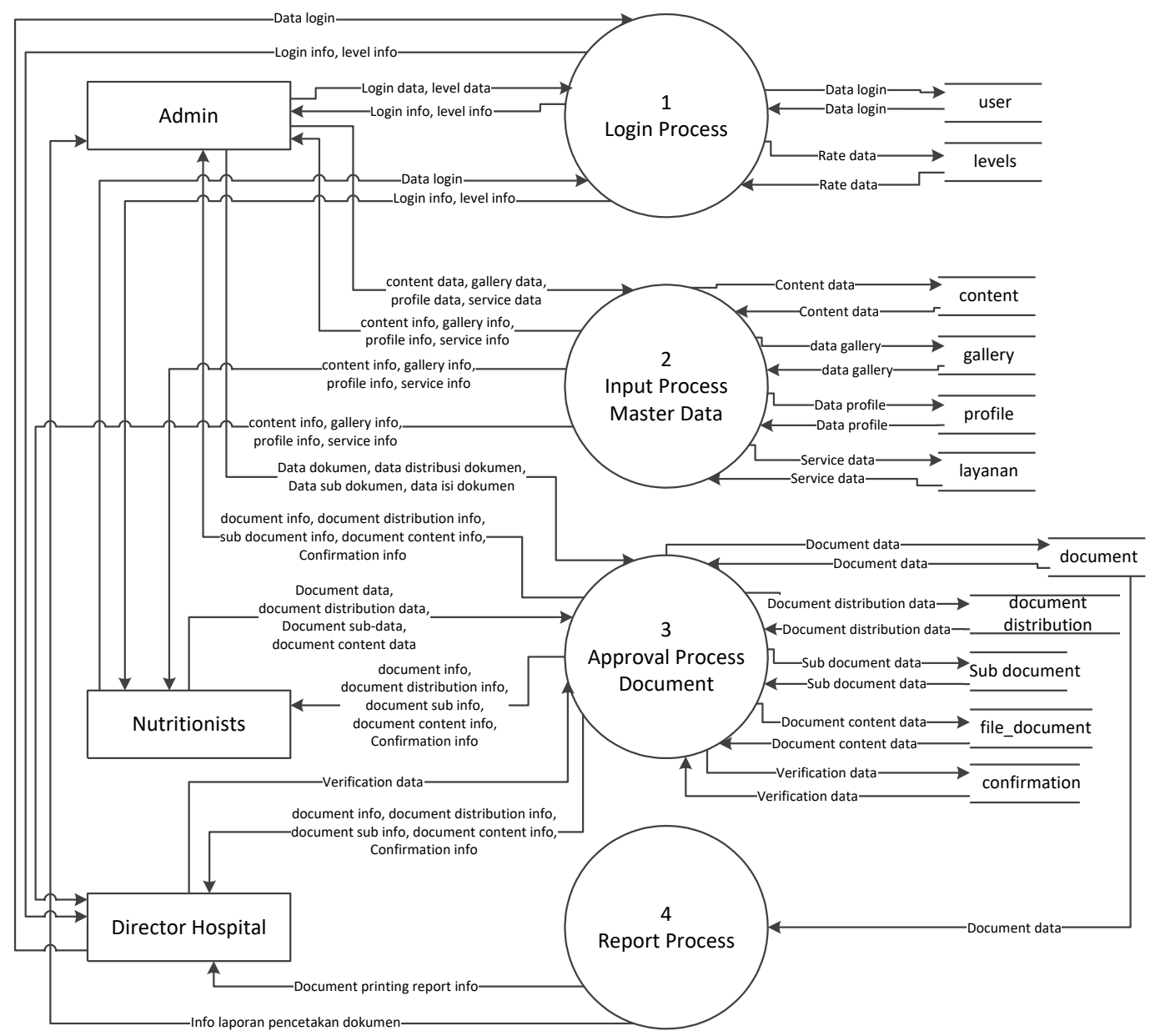

Fig.6: DFD (Data Flow Diagram)

Level 1 In Figure 6 the process diagram level 1 Information Systems in Supporting Nutrition Services are as follows:

\section{Login Process}

In this process, the system user is an admin who is given access rights in the system, each of which enters the login data and stores it in the database which is then generated in the form of output, namely username and password.

\section{Master Data Input Process}

In this process, the task of a nutritionist is to input incoming data to fulfill the requirements for halal assurance certification.

\section{Document Validation Process}

In this process, the Hospital Director's job is to approve document validation.

\section{Report Process}

In this process, system users can enter the report data they want to show according to the desired timeframe they want to print.

\section{7) ERD}




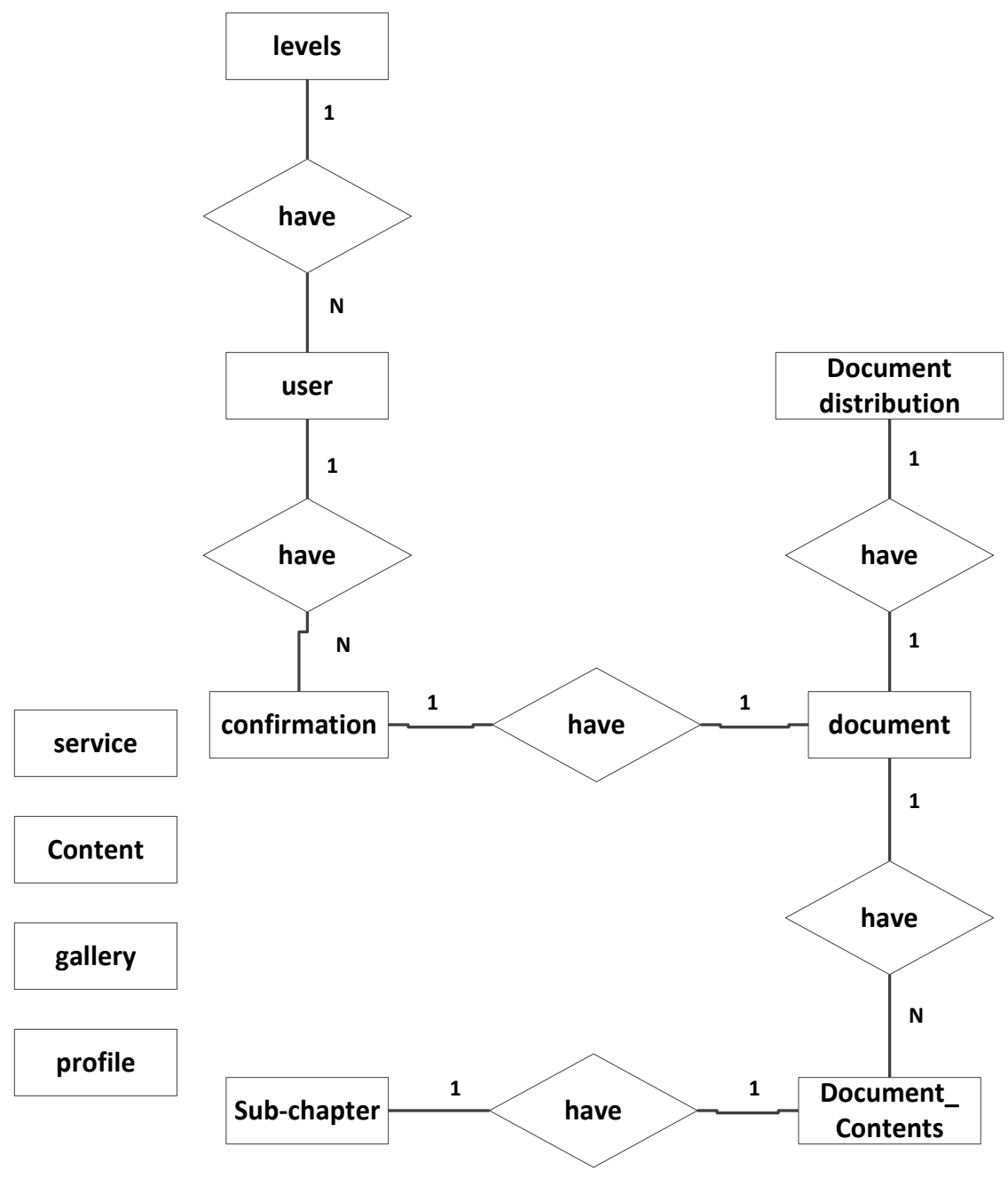

Fig.7: ERD (Entity Relationship Diagram)

\section{RESULTS AND DISCUSSION}

The results and discussion on the analysis of information system requirements in supporting nutritional services based on halal assurance certification in hospitals are as follows:

A. Materials and Equipment:

The equipment used was the laptop and the computer used by respondents with operating system specifications: Windows 10, Intel R Celeron R CPU N2840 216 GHz, 2048MB RA memory. The applications used by researchers and IT are XAMP version 3.2.2 and PHP version 5.6.19. For the database server using PHP My Admin. And the programming language uses MySQL because it is easy and sufficient to represent what IT needs.
A. Interface
1. Main page

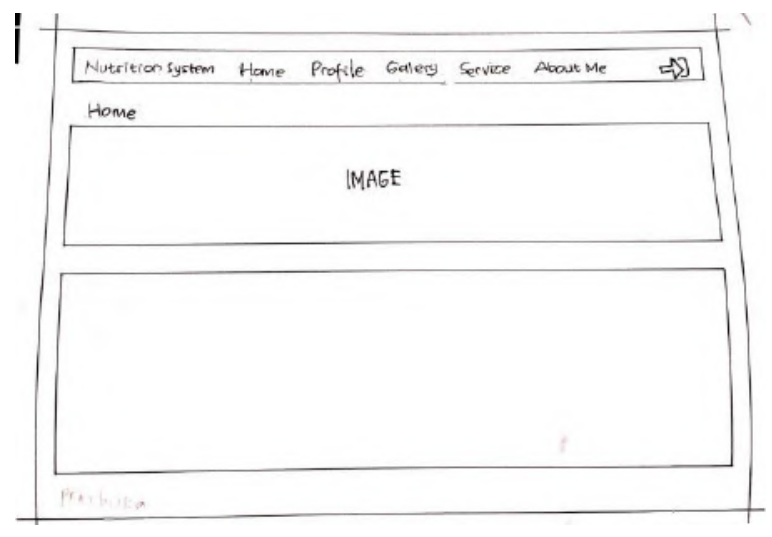

Fig.8: Main Page Interface

The picture above shows the initial design of the main page of the information system to support nutritional services based on halal certification in hospitals. 


\section{Login}

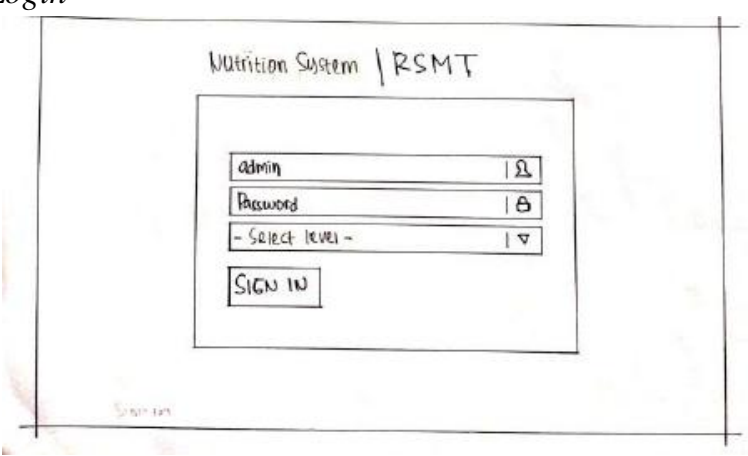

Fig.9: Login Menu Interface

The design image above shows the login menu design in the information system display in support of nutrition services based on halal certification in hospitals.

3. User Administrator System

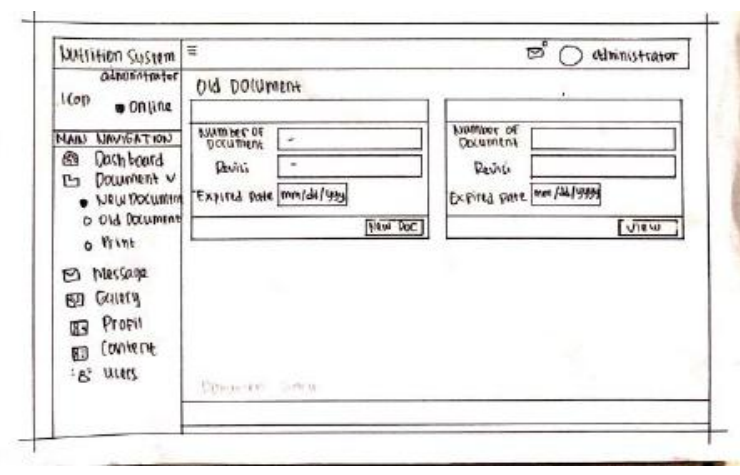

10. Interface User Administrator System

Figure

In the design image above, it shows the display for entering numbers in new documents or searching for old documents using the last date document created.

4. Old Document Data

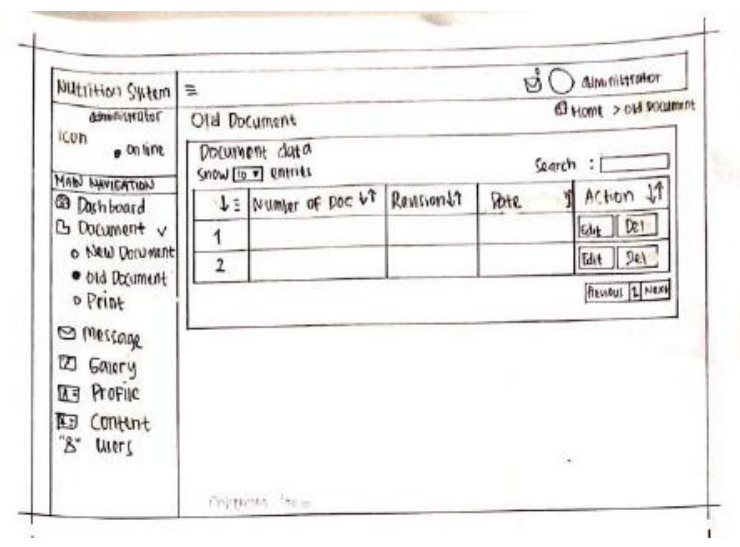

Fig.11: The interface of Old Document Data

5. Main page of document ratification

ISSN: 2456-7620

https://dx.doi.org/10.22161/ijels.56.49

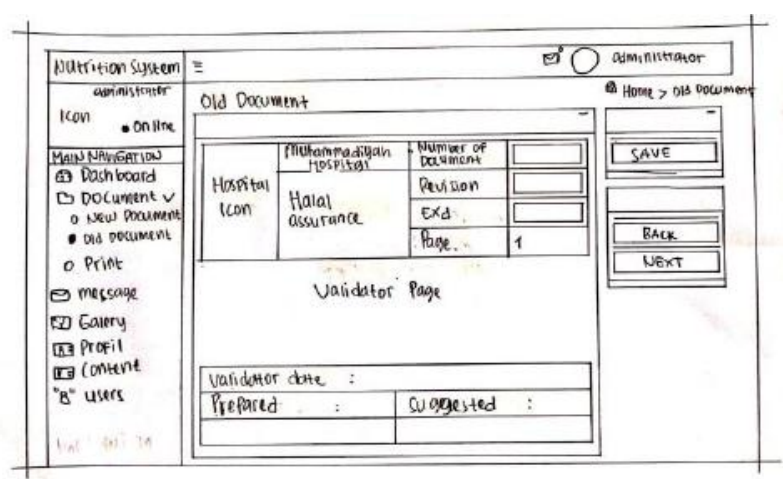

Fig.12: Interface Main Page Ratification of Documents

B. Implementation

1. Main Page

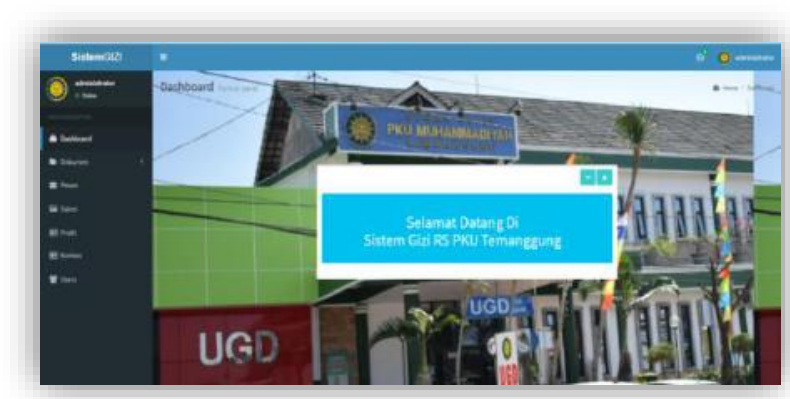

Fig.13: Image Main Page

2. The Login Menu Display

The Login menu which is the result of the previous interface design displaying the username, password, and levels are as follows:

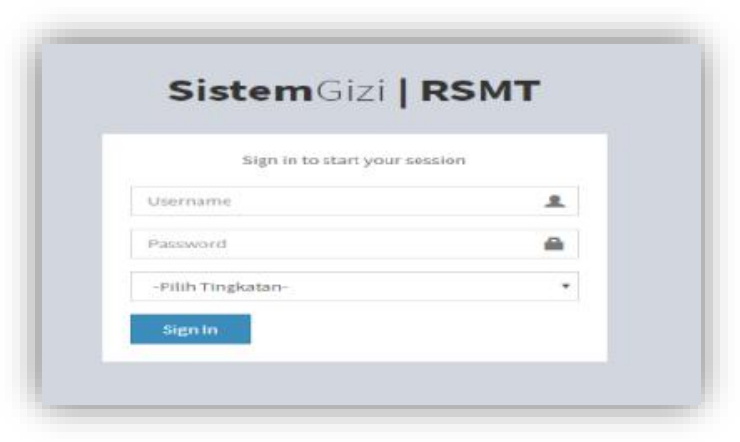

Fig. 14: Display Menu Login

\section{Display System Administrator User}

This user administrator view displays a menu of new documents and old documents in the form of document 
number, revision (how much, if the document is new it means the first revision)

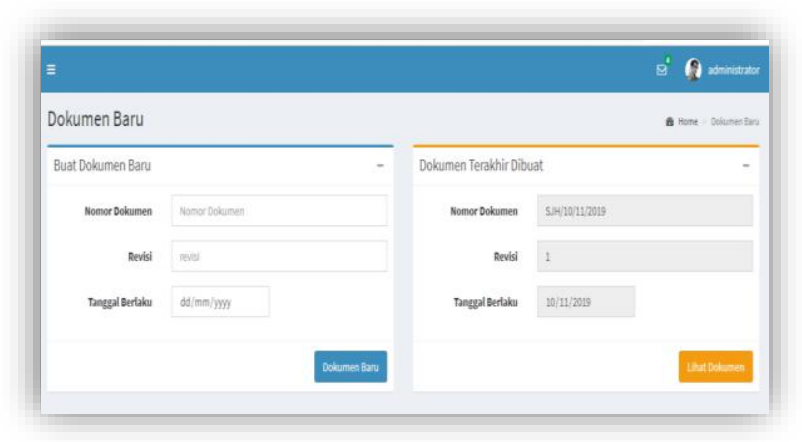

Fig.15: Main Display System Administrator User

\section{Display of Approval Page on New Document}

The validation page display in this new document is a document of approval from the hospital director for filling out the halal assurance certification document.

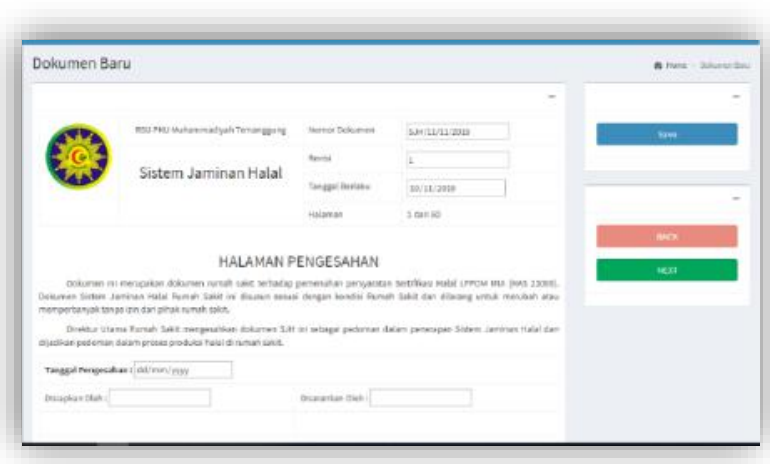

Fig.16: Approval Page on New Document

5. Display List of Distribution of Halal Assurance Certification Documents

From the distribution list view, this document explains who is responsible for each part of the nutrition installation such as quality control, distribution, etc.

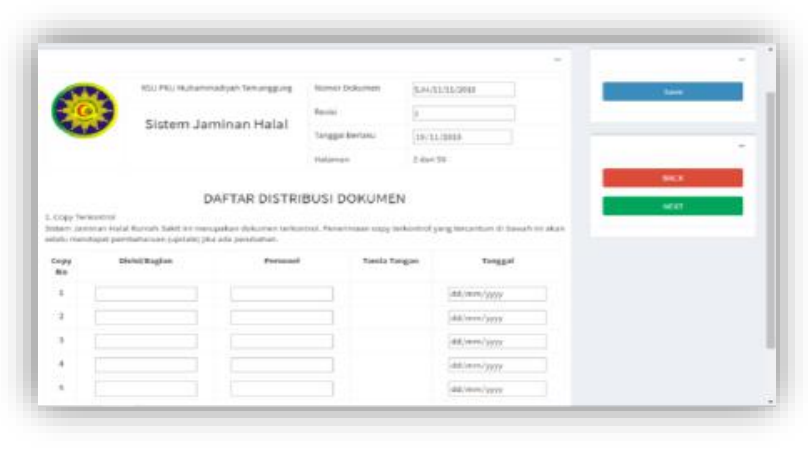

Fig. 17: Display of HAS Document Distribution List

\section{Display Document Retention Approval}

From the document retention approval view, it explains the consent of the system user whether he wants to save the document that the user has entered.

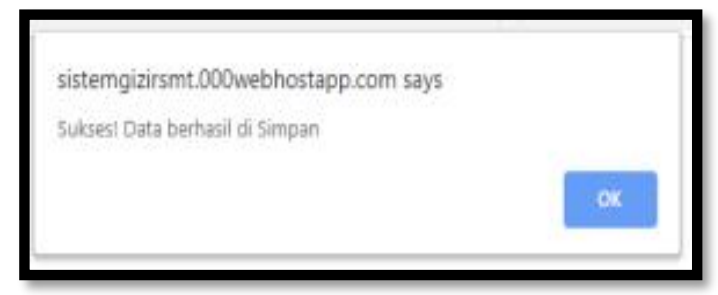

Fig.18: Display of Document Retention Approval

7. Display of one of the Halal Guarantee Certification Documents

In this display, system users, especially nutritionists, are asked to fill the hospital background in applying for halal assurance certification.

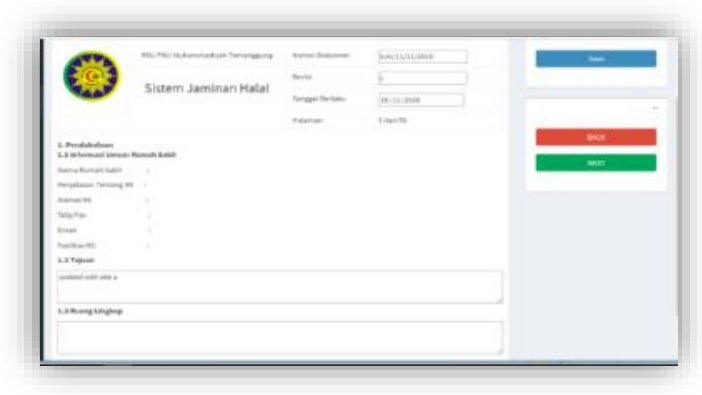

Fig.19: Display of one of the Halal Assurance Certification Documents 
8. Display After Completing Completion of Halal Assurance Certification Documents

This view indicates that the document has been completed.

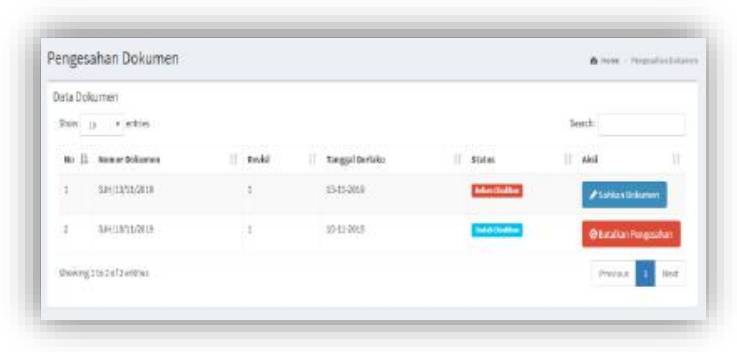

Fig.20: Display After Completing Completion of HAS Documents

9. Display of Document Approval by the Director This view shows the approval page which only the director can do before the document can be printed.

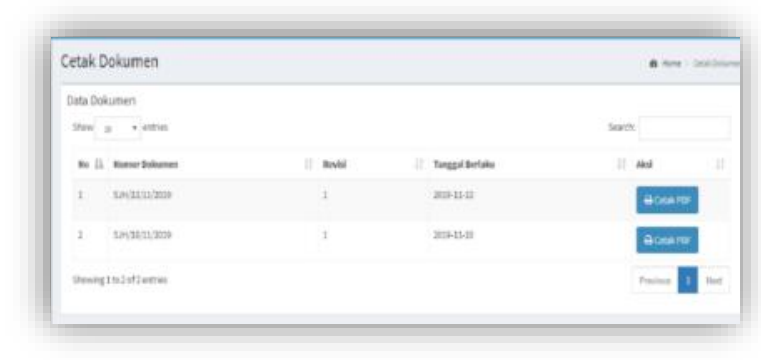

Fig.21: Views of Document Approval by Director 3. Page Views for Document Printing. The display below shows if the document is ready to be printed.

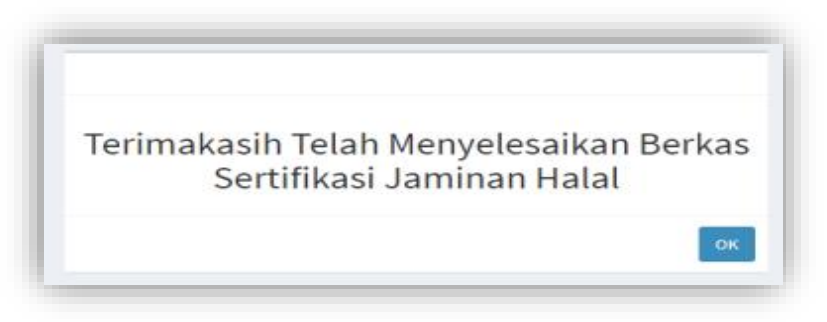

Fig.22: Views To Print Documents

10. Approvals Page View Printing Documents

The display below shows whether the system user agrees to print the document.

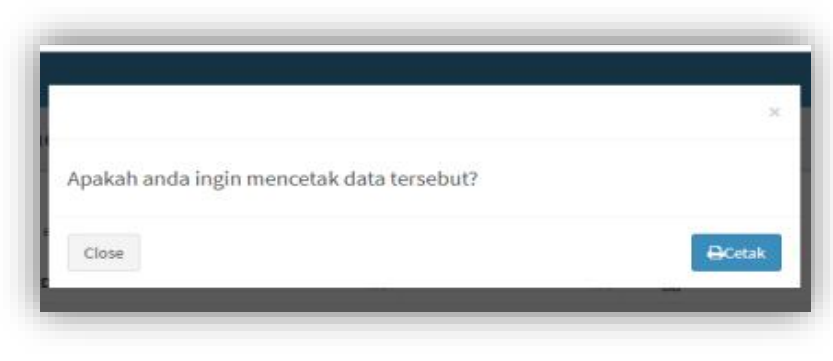

Fig.23: Views of the Approval Page for Printing Documents

11. Display Documents That Have Been Printed in PDF Format.

The page view below shows the results of the completed document in PDF format.

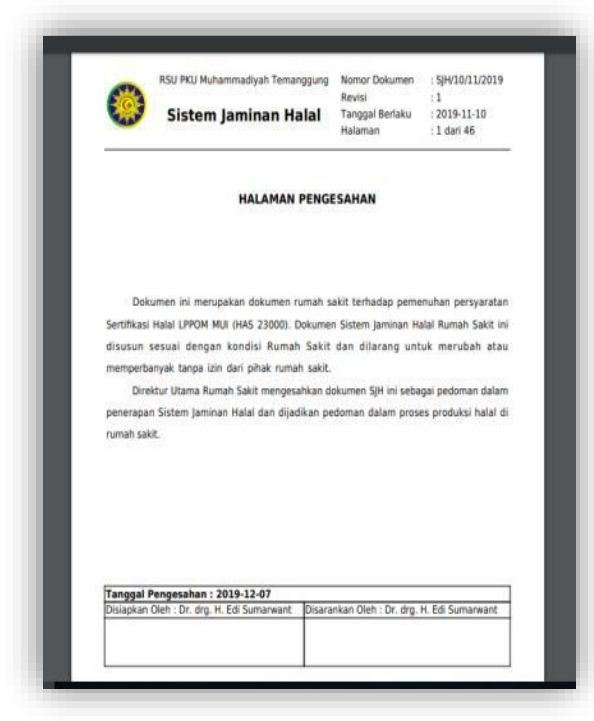

Fig.24: Document View in PDF Format

\section{CONCLUSION}

Based on the results of the research that has been presented above, it can be concluded that the research with the title Design of Information Systems in Support of Nutritional Services Based on Halal Assurance Certification in Hospitals. The things obtained are as follows:

1. Design of Information Systems in Support of Nutritional Services Based on Halal Assurance Certification in Hospitals using PHP My Admin has successfully carried out the design with the results that can be seen in chapter 3. From this system, distribution data, quality control, warehouse, production, materials 
standards can produce halal assurance certification document reports.

2. Based on the results of implementing the system and interviews with system users, the Information System in Supporting Nutrition Servants Based on Halal Assurance Certification can be said to be as expected, useful, and can help hospitals in managing halal assurance certification for hospitals.

\section{ACKNOWLEDGMENT}

The author would like to thank the Director of the PKU Muhammadiyah Temanggung Islamic Hospital for permitting doing the research.

\section{REFERENCES}

[1] Departement of Health-Menterium- level rule Indonesian Republican Number 782013 Nutrition in Hospital . In: Permenkes. Vol 84. Jakarta; 2013:487-492.

[2] Mei J, Anne C. Article Positioning Food Safety in Halal Assurance Positioning Food Safety in Halal Assurance. Univ Cent iunLanchasire. 2016:0-2.

[3] Othman B. The potential of ASEAN in halal certification implementation: A review SOCIAL SCIENCES \& HUMANITIES The Potential of ASEAN in Halal Certification Implementation: A Review. Soc Sci Humanit. 2016; (September).

[4] Dwanoko YS. Implementasi Software Development Life Cycle ( Sdlc) Dalam Penerapan Pembangunan Aplikasi Perangkat. J Teknol Inf. 2016.

[5] N IAH, Santoso PI, Ferdiana R. Pengujian Usability Website Menggunakan System Usability Scale Website Usability Testing using System Usability Scale. 2015.

[6] Soejono AW, Setyanto A, Sofyan AF, Anova W. Evaluasi Usability Website UNRIYO Menggunakan S ystem Usability Scale ( Studi Kasus : Website UNRIYO ). 2018.

[7] Joshi A, Kale S, Chandel S, Pal D. Likert Scale: Explored and Explained. Br J Appl Sci Technol. 2015.

[8] Lewis JR, Sauro J. The factor structure of the system usability scale. Lect Notes Comput Sci (including Subser Lect Notes Artif Intell Lect Notes Bioinformatics). 2009.

[9] Shafii Z, Zain SN. Halal Assurance Mechanisms In Halal Industry: An Appraisal On Its Effectiveness Towards Continuous Halal Assurance and The Way Forward. 2015.

[10] Azizah AZ, Darni J, Damayanti AY, Naufalani MD. The Difference Level of Satisfaction Eating the Patient at The Hospital with Halal Assurance and not. . Ghidza J . Health and Nutrition (2019). 